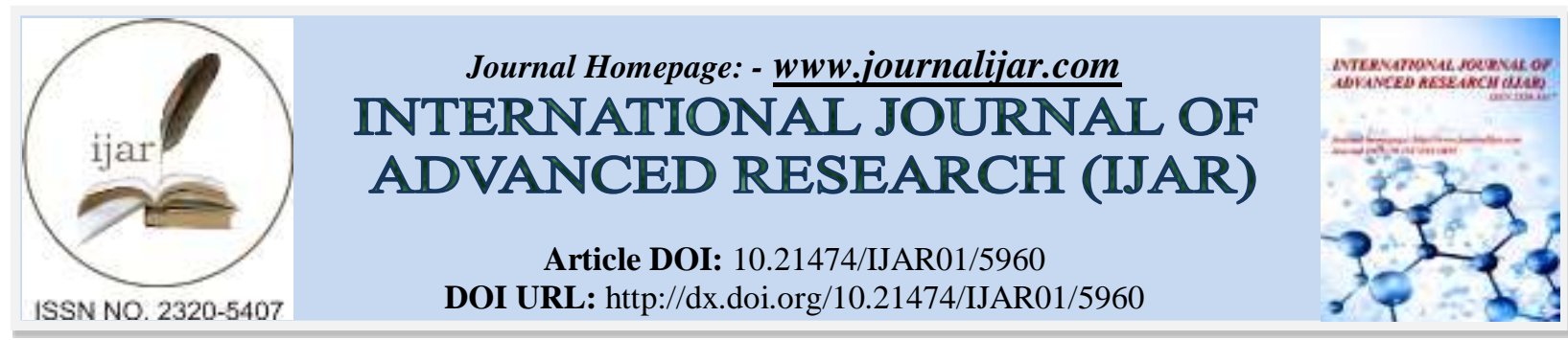

RESEARCH ARTICLE

\title{
THE EFFECT OF RED CHILI (CAPSICUM ANNUUM L.) SOAKING IN ASCORBIC ACID SOLUTION ON CHARACTERISTICS OF CHILI POWDER.
}

Rina Yenrina ${ }^{1}$, Kesuma Sayuti ${ }^{1}$, Bobby Andhika ${ }^{1}$ and Sri Darningsih ${ }^{2}$.

1. Faculty of Agricultural Technology, University of Andalas. Padang 25163. Indonesia.

2. Department of Nutrition. Poltekkes KemenKes RI Padang. 25146. Indonesia.

\section{Manuscript Info}

Manuscript History

Received: 03 October 2017

Final Accepted: 05 November 2017

Published: December 2017

Key words:-

Characteristic, chili powder, ascorbic acid, chili, soaking.

\begin{abstract}
Red chili is an easily damaged agricultural product that needs to be processed, one of the processing that can be done is drying the red chili and then made into powder. To reduced the quality degradation during drying process used ascorbic acid which acted as an antioxidant: This study aimed to determine the effect of chili powder and obtaining the best ascorbic acid concentration in retaining the chemical content of chili powder. This study used Completely Randomized Design (CRD) with 5 treatments and 3 replications. Data were analyzed by analysis of variance (ANOVA), followed by Duncan's New Multiple Range Test (DNMRT) at the 5\% significance level. The treatment used was the difference in the concentration of ascorbic acid, A (0\%), B (2\%), C (4\%), D (6\%), E (8\%). The research result showed that the difference in vitamin $\mathrm{C}$ concentration, antioxidant activity, capsaicin content, oleoresins content and water activity. And was not significantly affected the color test and moisture content. The research results showed that ascorbic acid concentration of $8 \%$ (treatment E) was the best chili powder, with moisture content of $10.31 \%$, vitamin $\mathrm{C}$ of $165.73 \mathrm{mg} / \mathrm{g}$, capsaicin content of $4.71 \%$, water activity of 0.336 , color test of $89.58{ }^{\circ} \mathrm{Hue}$, antioxidant activity of $42.69 \%$, oleoresins content of $15.29 \%$.
\end{abstract}

Copy Right, IJAR, 2017,. All rights reserved.

\section{Introduction:-}

Red chili (Capsicum annuum L.) is one commodity that has high economic value, and one of the commodities consumed in large frequency by society in general. This is not separated from the culture of Indonesian society who are accustomed to consume red chili as a complementary herbs in various processed foods.

According to Prajnanta (1995) ${ }^{1}$, red chili, used as spices. The red color caused by carotenoid content in chili is used as a color in many traditional dishes. And added by the content of vitamin $\mathrm{C}$ and flavonoid components that usually act as antioxidants.

In addition to the appetite generator, chili with a spicy flavor has long been believed to be efficacious for health. Spicy taste in chili is caused by capsaicin. Capsaicin is found in seeds, skins, and chili flesh. Capsaicin is stomatic, which can increase appetite. Plus the ability to stimulate the production of endorphin hormones that can evoke the 
sensation of pleasure. Capsaicin is anticoagulant, keeping the blood diluted. It is useful to regulate blood circulation, strengthen the heart, pulse and nerves. Capsaicin also can thin the mucus, so it can loosen the blockage in the throat and nose. Awaken the spirit in the body and reduce the pain of arthritis and rheumatism (Prajnanta, 1995) ${ }^{1}$.

To extend the shelflife of red chili, efforts are made to develop processing technology. Like other horticultural commodities, red chili has a high water content. Foods that have high water content, have a risk of rapid deterioration (Wanda, 2013) ${ }^{2}$.

One of the processing wich was often done by making red chili powder. During the drying process, some of the nutrients contained in the chili oxidized. The content of nutrients oxidized include vitamin C, vitamin B1, oleoresin compounds that are volatile, and also carotenoids as a color pigment in chili. This leads to reduced nutritional content that is useful to the human body. Likewise with the color of the chili. The color of the chili will turn brownish (Muchtadi and Ayustaningwarno, 2010) ${ }^{3}$. Brownish color is caused by enzymatic browning reaction. The enzymatic browning reaction is a reaction caused by the presence of oxygen that reacted with the phenolic component contained in food material to form a brownish-colored melanin compound. Therefore it needed antioxidants to prevent oxidation of excessive chili nutritional content. One of the antioxidants that can be used was ascorbic acid (Vitamin C).

Based on the description above, the authors conducted a study with the title "The Effect of Red Chili (Capsicum Anпиит L.) Soaking in Ascorbic Acid Solution on Characteristics of Chili Powder".

\section{Research Methodology:-}

This research was conducted in Laboratory of Microbiology and Biotechnology, Laboratory of Chemical Biochemistry and Food Nutrition, Engineering and Process Technology of Agricultural Products, and Central Instrument Laboratory of Faculty of Agricultural Technology, University of Andalas. Padang.

Raw materials used in this study were red chili taken from District Limo Kaum, Tanah Datar regency. The chemicals used were ascorbic acid, aquades, starch indicator, iod $0.01 \mathrm{~N}$, ethanol, methanol, saturated salt and other materials.

Processing tools used included scales, basins, frying pans, stoves, digital oven. The analytical tools used were erlenmeyer, stirrer, funnel, measuring cup, glass cup, oven, measuring flask, pipette, aluminium plate, porcelain plate, desiccator, rotary vacuum, $\mathrm{a}_{\mathrm{w}}$ meter, Crhoma Meter and other tools

In this study, the design used was a complete randomized design (CRD) with 3 replications. If it was significantly different, it continued with Duncan's New Multiple Ranges Test (DNMRT) test at 5\% real level. The treatments used in this study were as follows:

Treatment A: 0\% Ascorbic acid solution

Treatment B: $2 \%$ Ascorbic acid solution

Treatment C: $4 \%$ Ascorbic acid solution

Treatment D: 6\% Ascorbic acid solution

Treatment E: 8\% Ascorbic acid solution

Implementation:-

Raw Material Preparation:-

A total of $7.5 \mathrm{~kg}$ of red chili prepared. The selected red chili was the chili that had the characteristics of flaming red color and the red chili reached the optimum size.

\section{Sorting and Cleaning:-}

Red chili was sorted based on similar size, skin color still fresh red, no defect. After sorted the chili cleaned of dirt on the skin of chili. The chili was also cleansed from the stalk. Chili that had been cleaned then washed with flowing water.

\section{Blanching:-}

Blanching process was done by boiling. Heat $3 \mathrm{~L}$ of water until the temperature reached $70^{\circ} \mathrm{C}$. Then put $1 \mathrm{Kg}$ of cleaned chili into water that has been heated and left for 6 minutes. After that the chili drained. 


\section{Soaking in Ascorbic Acid Solution:-}

Blanched chili then soaked in various concentrations of ascorbic acid using a closed container for 1 hour. The entire surface of the chili was soaked in ascorbic acid solution. The way of making ascorbic acid solution $2 \%, 4 \%, 6 \%$, and $8 \%$ was by dissolving $20 \mathrm{~g}, 40 \mathrm{~g}, 60 \mathrm{~g}$, and $80 \mathrm{~g}$ of ascorbic acid with water to $1 \mathrm{~L}$.

\section{Drying:-}

The soaked chili on the five ascorbic acid treatments then dried by drying the pepper oven for 20 hours at $60^{\circ} \mathrm{C}$. During drying, the material was flipped every 3 to 4 hours to dry evenly (Siswoputranto, 1973) ${ }^{4}$.

\section{Milling:-}

Red chili that has been dried milled using a blender to obtain red chili powder.

\section{Sifting:-}

Chili powder that had been obtained then sifted using a sieve of 60 mesh. Then the chili powder packed using a dark glass bottle packaging. Chili powder was ready to analyzed.

\section{Observation:-}

The observations made on chili powder were vitamin $\mathrm{C}$ (iodometric), moisture content (gravimetric), capsaicin (gravimetric), antioxidant activity (DPPH), water activity $\left(\mathrm{A}_{\mathrm{w}}\right.$ meter), oleoresin content (gravimetric), color test (Crhoma Meter).

\section{Results And Discussion:- Moisture Content:-}

Based on analysis of variance, soaking treatment in ascorbic acid showed no significant effect on moisture content of chili powder at the significant level $\alpha=5 \%$. The average value of powdered chili moisture content can be seen in Table 1. Based on the Table 1 showed that the average moisture content of chili powder ranged between $9.91 \%$ $10.48 \%$. The highest average moisture content was found in treatment A (without soaking in ascorbic acid solution), while the lowest average moisture content was found in treatment B ( $2 \%$ ascorbic acid solution).

Moisture content was an important parameter because the moisture content affected the chili powder. In this research, moisture content analysis was done to know the amount of water contained in chili powder product. This was in accordance with the opinion of Winarno $(2004)^{5}$ that water is an important component in foodstuffs because water can affect the appearance, texture, and taste of food.

The water content in the foodstuffs also determines the freshness and shelf life of the food, high moisture content made it easy for bacteria, mold, and yeast to breed, so that there will be changes in foodstuff (Gobel, 2012) ${ }^{6}$.

The standard moisture content of powder spices which is permitted was a maximum of $12 \%$, according to SNI 01$3709-1995^{7}$. Based on this standard, the resulting chili powder product had fulfilled the quality requirements of powder spices. While the moisture content of commercial chili powder obtained of $9.78 \%$. The value was not too much different from the value of moisture content of chili powder produced.

\section{Vitamin C:-}

Based on analysis of variance, soaking treatment on ascorbic acid showed significantly different effect on vitamin C content of chili powder produced at the level of real $\alpha=5 \%$. Different treatments were performed by DNMRT advanced test at $5 \%$ real level. The average value of vitamin $\mathrm{C}$ content can be seen in Table 2 . Based on the table showed that the value of vitamin $\mathrm{C}$ content of chili powder ranged between $31.39 \mathrm{mg} / \mathrm{g}-165.73 \mathrm{mg} / \mathrm{g}$. The highest vitamin $\mathrm{C}$ was found in treatment $\mathrm{E}$ ( $8 \%$ ascorbic acid solution). While the lowest value found in treatment $\mathrm{A}$ (without soaking in ascorbic acid). This was indicated that the higher concentration of ascorbic acid increased the vitamin $\mathrm{C}$ content in the resulting chili powder.

Vitamin C content obtained showed a significant increased as the addition of ascorbic acid concentration on chili. This was because ascorbic acid was can antioxidant that minimized the oxidation of vitamin $\mathrm{C}$ in chili. High levels of vitamin $\mathrm{C}$ in some treatments were due to high concentrations of ascorbic acid added so as to increased vitamin $\mathrm{C}$ content of chili powder. 
According to Andira (2017) $)^{8}$ vitamin C is one of powerful antioxidants. This was directly proportional to the results obtained. The addition of ascorbic acid was able to maintain vitamin $\mathrm{C}$ levels from oxidation due to heating. In treatment $\mathrm{D}$ (6\% ascorbic acid solution) and $\mathrm{E}$ ( $8 \%$ ascorbic acid solution), vitamin $\mathrm{C}$ value even exceeded vitamin $\mathrm{C}$ levels in the material. This may be due to the large concentrations of ascorbic acid entered the material during the soaking, this made the vitamin $\mathrm{C}$ content increased before the drying process.

\section{Water Activities (Aw):-}

Based on the analysis of variance, soaking treatment in ascorbic acid showed significantly different effect on the value of water activity of chili powder obtained at the significance level of $\alpha=5 \%$. Different treatment was performed by DNMRT advanced test at $5 \%$ real level. The average value of water activity of chili powder can be seen in Table 3. Based on the table showed that the average value of water activity of chili powder ranged from $0.336-0.470$. The highest water activity value was found in treatment A (without soaking in ascorbic acid solution). While the lowest water activity value was found in treatment E (8\% ascorbic acid solution). This was thought to occur because ascorbic acid bound water to the material, resulting in low water activity.

Water activity was closely related to food shelf life. One of the factors that caused food damage was microbial growth. The commonly, the microbes grow at $\mathrm{a}_{\mathrm{w}}$ around 0.60-1.00. At $\mathrm{a}_{\mathrm{w}}$ below 0.60 microbes are generally difficult to grow because there is not enough free water available to support their growth (Kusnandar, 2010)

The value of the $a_{w}$ can be adjusted to obtain a better preservation rate. For each type of food, the $a_{w}$ changed to the most appropriate (ie, optimum) was aimed to get the material in best condition so that during storage, its contents, shape and appearance were always favored (Ruus, 2009) ${ }^{10}$.

Table 1:- Average Value of Moisture Content of Chili Powder

\begin{tabular}{|l|c|}
\hline \multicolumn{1}{|c|}{ Treatments } & Moisture Content $(\%) \pm$ SD \\
\hline A (0\% ascorbic acid solution) & $10.48 \pm 0.47$ \\
\hline B (2\% ascorbic acid solution) & $9.91 \pm 0.35$ \\
\hline C (4\% ascorbic acid solution) & $10.08 \pm 0.11$ \\
\hline D (6\% ascorbic acid solution) & $10.44 \pm 0.46$ \\
\hline E (8\% ascorbic acid solution) & $10.31 \pm 0.53$ \\
\hline CV $=4.01 \%$ & \\
\hline
\end{tabular}

Table 2:- Average Value of Vitamin C content of Chili Powder

\begin{tabular}{|l|l|}
\hline \multicolumn{1}{|c|}{ Treatments } & Vitamin C $(\mathrm{mg} / \mathrm{g}) \pm \mathrm{SD}$ \\
\hline $\mathrm{A}(0 \%$ ascorbic acid solution) & $31.39 \pm 3.00 \mathrm{a}$ \\
\hline $\mathrm{B}(2 \%$ ascorbic acid solution) & $54.27 \pm 2.86 \quad \mathrm{~b}$ \\
\hline $\mathrm{C}(4 \%$ ascorbic acid solution) & $60.13 \pm 2.65 \quad \mathrm{~b}$ \\
\hline $\mathrm{D}(6 \%$ ascorbic acid solution) & $130.53 \pm 4.70 \mathrm{c} \quad$ \\
\hline $\mathrm{E}(8 \%$ ascorbic acid solution) & $165.73 \pm 3.74 \quad \mathrm{~d}$ \\
\hline $\mathrm{CV}=5.52 \%$ & \\
\hline
\end{tabular}

Table 3:- Average Value of Water Activity of Chili Powder

\begin{tabular}{|l|l|}
\hline \multicolumn{1}{|c|}{ Treatments } & Aw \pm SD \\
\hline E (8\% ascorbic acid solution) & $0.336 \pm 0.01$ a \\
\hline B (2\% ascorbic acid solution) & $0.349 \pm 0.02$ a \\
\hline C (4\% ascorbic acid solution) & $0.392 \pm 0.01 \quad \mathrm{~b}$ \\
\hline D (6\% ascorbic acid solution) & $0.430 \pm 0.01 \quad \mathrm{c}$ \\
\hline A (0\% ascorbic acid solution) & $0.470 \pm 0.01 \quad$ d \\
\hline CV $=2.53 \%$ & \\
\hline
\end{tabular}

Table 4:- Average Value of Color of Chili Powder

\begin{tabular}{|l|c|}
\hline \multicolumn{1}{|c|}{ Treatments } & Color $\left({ }^{0} \mathrm{Hue}\right) \pm \mathrm{SD}$ \\
\hline $\mathrm{A}(0 \%$ ascorbic acid solution) & $96.31 \pm 4.28$ \\
\hline $\mathrm{B}(2 \%$ ascorbic acid solution) & $89.68 \pm 4.70$ \\
\hline
\end{tabular}




\begin{tabular}{|l|l|}
\hline C (4\% ascorbic acid solution) & $88.16 \pm 1.83$ \\
\hline $\mathrm{D}(6 \%$ ascorbic acid solution) & $88.73 \pm 4.93$ \\
\hline $\mathrm{E}(8 \%$ ascorbic acid solution) & $89.58 \pm 2.80$ \\
\hline $\mathrm{CV}=4.31 \%$ & \\
\hline
\end{tabular}

Table 5:- Average Value of Antioxidant Activity of Chili Powder

\begin{tabular}{|l|c|}
\hline \multicolumn{1}{|c|}{ Treatments } & Antioxidant Activity $(\%) \pm$ SD \\
\hline $\mathrm{A}(0 \%$ ascorbic acid solution) & $14.14 \pm 3.76 \mathrm{a}$ \\
\hline $\mathrm{B}(2 \%$ ascorbic acid solution) & $16.73 \pm 2.19 \mathrm{a}$ \\
\hline $\mathrm{C}(4 \%$ ascorbic acid solution $)$ & $35.74 \pm 4.10 \mathrm{~b}$ \\
\hline $\mathrm{D}(6 \%$ ascorbic acid solution) & $38.72 \pm 3.04 \mathrm{~b} \mathrm{c}$ \\
\hline $\mathrm{E}(8 \%$ ascorbic acid solution) & $42.69 \pm 3.41 \quad \mathrm{c}$ \\
\hline $\mathrm{CV}=11.37 \%$ & \\
\hline
\end{tabular}

Table 6:- Average Value of Capsaicin Content of Chili Powder

\begin{tabular}{|l|c|}
\hline \multicolumn{1}{|c|}{ Treatments } & Capsaicin $(\%) \pm$ SD \\
\hline $\mathrm{A}(0 \%$ ascorbic acid solution) & $3.10 \pm 0.65$ a \\
\hline $\mathrm{B}(2 \%$ ascorbic acid solution) & $3.71 \pm 0.10$ a b \\
\hline C (4\% ascorbic acid solution) & $3.84 \pm 0.10 \quad$ b \\
\hline $\mathrm{D}(6 \%$ ascorbic acid solution) & $4.66 \pm 0.25 \quad \mathrm{c}$ \\
\hline $\mathrm{E}(8 \%$ ascorbic acid solution) & $4.71 \pm 0.33 \quad \mathrm{c}$ \\
\hline $\mathrm{CV}=8.76 \%$ & \\
\hline
\end{tabular}

Table 7:- Average Value of Oleoresins Content of Chili Powder

\begin{tabular}{|c|c|}
\hline Treatments & Oleoresins $(\%) \pm \mathrm{SD}$ \\
\hline A (0\% ascorbic acid solution) & $12.02 \pm 1.40 \quad \mathrm{a}$ \\
\hline B (2\% ascorbic acid solution) & $13.03 \pm 0.72$ \\
\hline $\mathrm{C}(4 \%$ ascorbic acid solution) & $13.84 \pm 0.63$ \\
\hline $\mathrm{D}(6 \%$ ascorbic acid solution) & $14.52 \pm 1.52$ \\
\hline E (8\% ascorbic acid solution) & $15.29 \pm 1.21$ \\
\hline $\mathrm{CV}=8.40 \%$ & \\
\hline
\end{tabular}

Note: The numbers on the same line followed by the same lowercase letters are not significantly different according to DNMRT at the 5\% real level.

\section{Color:-}

Based on the analysis of variance, the treatment of soaking in ascorbic acid showed no significant different effect on the level of $\alpha=5 \%$. The average value of color of chili powder can be seen in table 4 . Based on table 4 the value of ${ }^{\circ} \mathrm{Hue}$ of chili powder's color analysis was ranged between 88.16-96.31. The chili powder product was generally yellow-red colored, except for the treatment A (without soaking in ascorbic acid) of yellow color. According to Astawan and Leomitro (2008) ${ }^{11}$ red color in chili caused by lycopene content, where lycopene is member of pigment from carotenoid. Farrel $(1990)^{12}$ suggested that carotenoid pigments, capsanthin, carotene and zeaxanthin contribute to the red color of chili.

Carotenoids was unstable when exposed by light, oxidizing, and heat. The double bond in the middle of the carotenoid chain was susceptible to oxidastor attacks. The oxidation process of carotenoids was stimulated by the presence of light, heat, peroxidation, metals such as Fe, and enzymes. Oxidation caused carotenoids lost their activity. The addition of antioxidants such as ascorbic acid increased the stability of carotenoids (Andarwulan and Faradilla, 2012) $)^{13}$.

Drying process of food changes the color of food. Carotenoids can also be damaged during drying process, which eventually changes the color. The higher the temperature and the duration of the drying, the more the colorant stuffs changed. To reduce browning process and color change due to drying sulfite, phosphate and carbonate should be used in blanching (Muchtadi and Ayustaningwarno et al, 2010) ${ }^{3}$. 


\section{Antioxidant Activity:-}

Based on analysis of variance, soaking treatment in ascorbic acid showed significantly different effect to the value of antioxidant activity at real level of $\alpha=5 \%$. The average value of antioxidant activity of chili powder can be seen in Table 5. Based on the table can be seen that the range of antioxidant value in chili powder ranged between $14.14 \%-42.69 \%$. The average value of the lowest antioxidant activity was in treatment A (without soaking in ascorbic acid solution), while the highest value was in treatment E (8\% ascorbic acid solution).

This was because the ascorbic acid that added was antioxidant that has the ability to catch free radicals and prevent oxidation reactions by DPPH compounds. DPPH solution acted as a free radical that reacted with antioxidant compounds so DPPH turn into non-radical. It was shown by the color of the solution marked by the change of dark purple to pink (Sayuti and Yenrina, 2015) ${ }^{14}$.

According to Muchtadi and Ayustaningwarno (2010) ${ }^{3}$, vitamin C is a powerful antioxidant, because it can donate hydrogen atoms and form a relatively stable ascorbilic free radical. This can be seen from the value of antioxidant activity of chili powder increased as the addition of ascorbic acid concentration.

The value of antioxidant activity can also affected by compounds that in chili that had phytochemical properties. Compounds contained in chili are compounds of phenol, flavonoids, vitamin E, beta-carotene, carotenoid pigments and capsaicin (Alex, 2012) ${ }^{15}$. It was suspected that the compounds were not oxidized during drying process due to the addition of ascorbic acid as a protective agent.

\section{Capsaicin :-}

Based on analysis of variance, soaking treatment in ascorbic acid showed significantly different effect on capsaicin content of chili powder produced at the level of real $\alpha=5 \%$. Different treatment was performed by DNMRT advanced test at 5\% real level. The average value of capsaicin chili powder can be seen in Table 6 . Based on the table it can be seen that the average value of capsaicin content in chili powder ranged between $3.10 \%-4.71 \%$. The lowest capsaicin content was found in treatment A (without soaking in ascorbic acid solution). While the highest capsaicin content was found in treatment $\mathrm{E}$ (8\% ascorbic acid solution).

Soaking treatment in ascorbic acid solution affected the capsaicin content in chili powder. Seen from the results obtained that the higher concentration of ascorbic acid solution given, the higher the content of capsaicin in chili powder. The addition of ascorbic acid as an antioxidant to chili was retain the capsaicin compound from oxidation during the drying process. According to Andarwulan and Faradilla (2012) ${ }^{13}$ antioxidant compounds serve to protect food from damage caused by the oxidation reaction.

According to Hasrayanti (2013) ${ }^{16}$, other factors that can affect the high levels of capsaicin is the drying temperature and the duration of drying. Capsaicin was very susceptible to hot conditions so that the temperature and duration of drying to reduce water content greatly affects the loss of capsaicin in chili. Therefore, on chili drying process used temperature at $60^{\circ} \mathrm{C}$ which was considered as the optimum temperature so that it minimized the loss of capsaicin content in chili.

\section{Oleoresin:-}

Based on the analysis of variance, soaking treatment in ascorbic acid showed significantly different effect on the oleoresin content in chili powder produced at the level of real $\alpha=5 \%$. Different treatment was performed by DNMRT advanced test at 5\% real level. The average value of oleoresin content in chili powder can be seen in Table 7. Based on the table showed that the average value of oleoresin content in chili powder ranged between $12.02 \%$ $15.29 \%$. The lowest oleoresin content was found in treatment A (without soaking in ascorbic acid solution). While the highest oleoresin content was found in treatment $\mathrm{E}$ (8\% ascorbic acid solution).

The application of soaking treatment in ascorbic acid affected the oleoresin content in chili powder. The high value of oleoresin also depended on the value of capsaicin in chili powder. This was supported by the opinion of Setyaningrum $(2013)^{17}$ that the main compound that constitutes oleoresin in chili is capsaicin. The addition of ascorbic acid was able to retain capsaicin from the oxidation reaction. The higher the concentration of ascorbic acid solution, the capsaicin content increased. The higher the value of capsaicin content, it further increased the value of oleoresin in chili powder. The value of oleoresin content obtained in commercial chili powder was $13.64 \%$. 
Factors that influence the high value of oleoresin content in chili powder is solvent type, particle size, extraction time, temperature and the speed of stirring. The oleoresin content obtained consists of various components such as essential oils, resins, spice components, pigments, vitamins, carbohydrates and sterols (Setyaningrum, 2013) ${ }^{17}$.

According to Ravindarn et al $(2007)^{18}$, oleoresin extraction consists of three stages. First the process of raw material contact with the solvent it made the movement of active component of raw materials into the solvent. The next stage of separation of the solution with raw materials, so obtained extracts solution and dregs. The final stage was the process of distillation of the solvent, so it became oleoresin.

\section{Conclusion:-}

Based on the research that has been done can be concluded as follows:

1. From the result of research of the best chili powder that produced was at treatment E (concentration of $8 \%$ ascorbic acid solution) with characteristic as follows: moisture content of $10.31 \%$, vitamin C of $165.73 \mathrm{mg} / \mathrm{g}$, capsaicin content of $4.71 \%$, water activity of 0.336 , color test of $89.58{ }^{\circ}$ hue, antioxidant activity of $42.69 \%$, oleoresin content of $15.29 \%$.

2. The effect of red chili soaking in ascorbic acid solution on characteristics of chili powder significantly affected vitamin $\mathrm{C}$ content, antioxidant activity, capsaicin content, oleoresin content, and water activity. However, no significant effect on color test and moisture content.

\section{Significance Statement:-}

Soaking red chili with vitamin $\mathrm{C}$ before drying can reduce the quality decline of the chili powder. Based on the research that has been done, it is recommended to try drying the red chili soaked with ascorbic acid using vacuum drying method.

\section{References:-}

1. Prajnanta, F. 1995. Agrobisnis Cabai Hibrida. Penebar Swadaya. Jakarta

2. Wanda, S. 2013. Pengaruh Lama Blansir Cabai Merah Keriting (Capsicum annuum, L.) dalam Larutan Dipsol Terhadap Mutu Cabai Merah Keriting Utuh. Fakultas Teknologi Pertanian. Universitas Andalas. Padang.

3. Muchtadi, T. R. and F. Ayustaningwarno. 2010. Teknologi Proses Pengolahan Pangan. Alfabeta. Bandung.

4. Siswoputranto, L.D. 1973. Percobaan Pengeringan Cabai Merah. Bull. Penel. Hort. Lembaga Penelitian Hortikultura Pasar Minggu. 1(4) : 5-12.

5. Winarno, FG., 2004. Pangan, Gizi, Teknologi dan Konsumen. Gramedia. Jakarta

6. Gobel, R.A. 2012. Studi Pembuatan Bumbu Inti Sambal Kering. Universitas Hasanuddin. Makassar

7. SNI 01-3709-1995. Rempah Rempah Bubuk. Badan Standar Nasional RI. Jakarta

8. Andira, A. 2017. Pengaruh Jenis Cabai (Capsicum sp.) dan Jenis Pati terhadap Mutu Saus. Universitas Andalas. Padang

9. Kusnandar, F. 2010. Kimia Pangan. Komponen Makro. Dian Rakyat. Jakarta.

10. Ruus, O. 2009. Pengaruh Konsentrasi Larutan Garam dan Lama Pengeringan Terhadap Mutu Ikan Layang. Fakultas Perikanan. Universitas Sam Ratulangi. Manado

11. Astawan, M., and A. Leomitro. 2008. Warna Warni Makanan. Gramedia. Jakarta

12. Farrel, KT. 1990. Spices, Condiments and Seasoning. Reinhold. New York.

13. Andarwulan, N., and R.H. Faradilla. 2012. Pewarna Alami Untuk Pangan. Seafast Center. Bogor.

14. Sayuti, K., and R. Yenrina. 2015. Antioksidan Alami dan Sintetik. Andalas University Press. Padang

15. Alex, S. 2012. Usaha Tani Cabai. Pustaka Baru Press. Yogyakarta:

16. Hasrayanti. 2013. Studi Pembuatan Bumbu Inti Cabai (Capsicum sp.) Dalam Bentuk Bubuk. Universitas Hasanuddin. Makassar.

17. Setyaningrum, LW. 2013. Ekstraksi Oleoresin Capsaicin Dari Cabai Merah, Cabai Keriting dan Cabai Rawit. Institut Pertanian Bogor. Bogor

18. Ravindarn, PN., Babu, K. Nirmal, and K. Sivarman. 2007. Turmeric: The Genus Curcuma. CRC Press. New York. 